\title{
The convergence of electricity and digitalization in the Netherlands
}

\section{Data governance as an emerging policy issue}

Romy Dekker, Rathenau Instituut, Anna van Saksenlaan 51, 2593 HW Den Haag (r.dekker@rathenau.nl)

Rinie van Est, Rathenau Instituut (q.vanest@rathenau.nl)

This paper explores the convergence of electricity and digitalization in the Netherlands. Based on the Advocacy Coalition Framework, we first show how the Paris Agreement on global warming in 2015 has led to a new renewable energy policy paradigm, in which digitalization plays a key enabling role. We will then show that the far-reaching convergence of electricity and digitalization pursued by European and Dutch policy makers will raise new policy issues. The core challenge is adequate energy data governance. Digitalization also raises policy issues in the areas of safety, consumer protection, democratic control, and equal distribution of costs and benefits in a digitized energy system. As the transition to a sustainable energy system must take place rapidly and energy data are expected to play a crucial role in achieving this, these issues are urgent.

\section{Die Konvergenz von Elektrizität und Digitalisierung in den Niederlanden \\ Data Governance als neues politisches Thema}

Dieser Artikel befasst sich mit der Konvergenz von Elektrizität und Digitalisierung in den Niederlanden. Anhand des Advocacy Coalition Framework zeigen wir zunächst, dass das Pariser Abkommen zur globalen Erwärmung im Jahr 2015 zu einem neuen Paradigma der Politik für erneuerbare Energien geführt hat, bei dem Digitalisierung eine zentrale Rolle spielt. Darüber hinaus werden wir zeigen, dass die weitreichende Konvergenz von Elektrizität und Digitalisierung, die von europäischen und niederländischen Politikern angestrebt wird, neue politische Fragen aufwerfen wird. Die zentrale Herausforderung ist ein entsprechendes Energiedatenmanagement. Darüber hinaus wirft die Digitalisierung auch politische Fragen im Bereich Sicherheit, Verbraucherschutz, demokratische Kontrolle und die gleichmäßige Verteilung von Kosten und Nutzen in einem digitalisierten Energiesystem auf. Da der Übergang zu

This is an article distributed under the terms of the Creative Commons Attribution License CCBY 4.0 (https://creativecommons.org/licenses/by/4.0/)

https://doi.org/10.14512/tatup.29.2.31

Submitted: 20.02.2020. Peer reviewed. Accepted: 15. 05.2020 einem nachhaltigen Energiesystem rasch erfolgen muss und Energiedaten hierfür voraussichtlich eine entscheidende Rolle spielen werden, sind diese Fragen dringend.

Keywords: global warming, digitalization, energy policy, data governance

In the Netherlands the digitalization of the electricity sector is in full swing: from the almost completed roll out of the smart meter to mushrooming energy platforms (Kloppenburg and Boekelo 2019). Current developments in the ICT-sector - advancements in data, analytics and connectivity - and the ongoing decarbonization of energy systems are expected to accelerate the convergence of digitalization and energy (IEA 2017). The Paris agreement of 2015 and the Dutch policy goals to come to a $49 \% \mathrm{CO}_{2}$ reduction by 2030 and a $95 \% \mathrm{CO}_{2}$ reduction by 2050, drive the emergence of large numbers of intermittent and often distributed energy resources (DER). As a result, electricity grids need to become smarter and in this way the convergence of electricity and digitalization is stimulated (Milchram et al. 2018; Tagliapietra et al. 2019). These rapid technological changes also require regulatory institutional changes (Koirala et al. 2018).

In this paper we explore the policy challenges associated with this scenario of far-reaching digitalization of the electricity sector pursued by Dutch policymakers. We take a policy perspective because public policies are major drivers of the desired sustainable energy transition (Markard et al. 2016). We use the Advocacy Coalition Framework (ACF) (Sabatier and Jenkins-Smith 1993) to study how global warming and climate policy are leading to major changes in energy policy and to gain insight into the policy challenges associated with the digitization of the electricity system. To do that the Dutch energy policy is, in line with ACF, conceptualized as a policy belief system. In doing so the paper contributes to policy process theories and, since policy changes are a crucial part of larger socio-technical transi- 
tions, holds relevance for sustainable transition studies (Kern and Howlett 2009; Markard et al. 2016).

Our policy analysis covers a long period of about 25 years: from 1995 to 2019. Our research is based on various relevant policy documents, such as the national energy policy reports of the Ministry of Economic Affairs and Climate which appear every four years. These energy reports look back at developments in recent years and determine the energy policy for the years to come. In addition, we analyzed the electricity law of 1998 and the Independent Network Management Act of 2006. Moreover, to verify our analysis, we organized several meetings with policy makers from the department of Economic Affairs and Climate, social scientists and experts from the energy sector to discuss our work.

The paper is structured as follows: in the following section we introduce the ACF. Next, we describe the influence of global warming and climate policy on energy policy. We will show that digitalization of the electricity sector has become a new policy core belief. We further analyze how the convergence of electricity with digitalization raises new policy issues. The conclusion discusses the implications of the analysis and highlights data governance as an emerging policy concern.

\section{The Advocacy Coalition Framework: a short description}

The ACF aims to understand the process of policy change over time (Sabatier and Jenkins-Smith 1993). It assumes that a focus on 'policy subsystems' - that is, those actors from a variety of public and private organizations who are actively concerned with a policy problem or issue - is a useful way to think about policy change over a period of more than a decade. Another basic premise of the ACF is that public policies (or programs) incorporate implicit theories about how to achieve their objectives and can thus be conceptualized in the same manner as belief systems, that is, as a set of value priorities, perceptions of the magnitude of the problem and causal assumptions about how to solve them.

According to the ACF, policy change over time is a function of three sets of processes. The first concerns the interaction of competing advocacy coalitions, that consist of actors who share a set of basic beliefs, within a subsystem. The second set of processes concerns changes external to the subsystem, like change of government or in socioeconomic or technological conditions. The third set involves the effects of stable system parameters, such as constitutional rules or the basic attributes of the problem area, on the constraints and resources of the various subsystem actors.

The ACF conceptualizes policy by means of policy belief systems and related policy change by means of changes in policy belief systems. The ACF distinguishes three hierarchical levels of beliefs: (1) Deep core beliefs refer to fundamental assumptions and worldviews and are very difficult to change. At the second level, policy core beliefs are about basic positions in a policy subsystem, e. g. with regard to the role of the state or the prominence and understanding of the policy issue. (2) Policy core beliefs encompass an entire policy subsystem and are hypothesized to be relatively stable over periods of a decade or more. (3) Secondary beliefs serve as premises for specific policies to be implemented or measures to be taken within a specific subsystem.

The ACF distinguishes between minor change as a result of changes in secondary beliefs and major policy change as a consequence of shifting core beliefs. According to the ACF, core beliefs will seldom change voluntarily (Sabatier and Weible 2007). Major external shocks, like the oil crisis or the Chernobyl nuclear disaster, are needed to cause major policy change. A major policy change can even result in a so-called policy paradigm shift (Hall 1993). In a policy paradigm shift, changes occur on each of the three levels of the policy belief system although certain dimensions of the old paradigm will remain after the shift (Salas Girones et al. 2019).

\section{Paris Agreement leads to major policy changes}

\section{Tracking changes in the energy policy belief systems}

In this section we analyze how a major change in climate policy, in particular the Paris Agreement in 2015, influenced Dutch energy policy. In terms of the ACF the Paris Agreement can be seen as a major external development which requires adjustment of energy policy and the energy system. The nation's ambition to come to a $49 \% \mathrm{CO}_{2}$ reduction by 2030 , has led to the Dutch government's decision to phase out fossil fuels and develop a cleaner, decentralized energy system, and thus new ways of producing and consuming (renewable) energy.

This section describes that the Paris Agreement has led to major energy policy changes. We use the ACF's three hierarchical levels of the energy policy belief system - deep core beliefs, policy core beliefs and secondary policy beliefs - to show that. We will describe the Dutch energy policy before and after the Paris Agreement. Because we see changes at both the deep core and policy core beliefs level, we conclude that the Paris climate treaty led to a paradigm shift in energy policy. The policy paradigm which characterized the Dutch energy policy between 1998 up to 2015 is named fossil energy market policy paradigm. The paradigm from 2015 onwards is called the renewable energy market policy paradigm (see table 1).

\section{Deep core beliefs}

Over the last two decades, affordability, reliability and clean energy have been the main goals or deep core beliefs of the Dutch energy policy (TK 1995; EZ 2008; EZLI 2011). These deep core beliefs should be achieved at the same time and are often referred to as a 'trilemma' (Edens 2017). Affordability refers to an energy system that is economically efficient and reliability relates to security of supply (EZ 2008). With a reliability 


\begin{tabular}{|l|l|l|}
\hline \multicolumn{2}{|l|}{ Fossil energy market policy paradigm (1998-2015) } \\
\hline Deep core beliefs & $\begin{array}{l}\text { Affordable } \\
\text { Reliable } \\
\text { (Somewhat) Clean (20\% in 2020) }\end{array}$ & $\begin{array}{l}\text { Affordable } \\
\text { Reliable } \\
\text { (Very) Clean (95\% in 2050) } \\
\text { Safe }\end{array}$ \\
\hline Policy core beliefs & $\begin{array}{l}\text { Liberalization } \\
\text { Privatization } \\
\text { Clean and efficient energy }\end{array}$ & $\begin{array}{l}\text { Liberalization } \\
\text { Privatization } \\
\text { Clean and efficient energy } \\
\text { Digitalization }\end{array}$ \\
\hline Secondary beliefs & $\begin{array}{l}\text { Promotion of clean/efficient energy } \\
\text { Electricity grid } \\
\text { Energy market design } \\
\text { Consumer protection framework }\end{array}$ & $\begin{array}{l}\text { Promotion of clean/efficient energy } \\
\text { Electricity grid } \\
\text { Energy market design } \\
\text { Consumer protection framework }\end{array}$ \\
\hline
\end{tabular}

Tab.1: Belief system change for Dutch energy policy.

of $99.994 \%$ of the Dutch electricity grid, it can be said that the Dutch energy system was successful in obtaining the deep core belief of reliability. Clean energy was defined as an energy supply with the highest possible environmental quality (EZ 2008). Even though the deep core of 'clean' has been pursued through various policies and goals over the years, in 2018, $90 \%$ of Dutch electricity was still provided by centralized coal and natural gas based power plants (CBS 2019). Consequently, it may be concluded that cleanliness was not a priority, as opposed to affordability and reliability. We refer to the policy paradigm during this time span as the fossil energy market policy paradigm.

After the Paris Agreement the political weight and policy interpretation of the deep core belief 'clean' changed drastically. To combat global warming, and in line with the Paris agreement of 2015, the Dutch government expressed in 2016 the ambition to strive for a low carbon energy supply that is reliable, affordable and, for the first time mentioned, safe (EZK 2016). Thus, even though the deep core belief of 'clean' remains the same word, its meaning and priority changes substantially under the influence of global warming.

\section{The Paris Agreement in 2015 has led to a paradigm shift in the Dutch energy policy.}

Dutch energy policy aims for $70 \%$ of electricity to be provided by renewable energy resources in 2030 (EZK 2019). To facilitate this, the Dutch energy system must undergo a drastic change from a centralized, fossil energy system to a more distributed, renewable energy system. Renewable energy resources are often intermittent and implemented at the distribution level, making it more complex to secure the reliability of the grid.
As a consequence, the electricity grid needs to be expanded by putting more cables in the ground. This is a very costly activity and in the Netherlands the costs for expanding the network are shared by all electricity consumers. All this leads to a greater challenge to continue safeguarding the reliability and affordability of the Dutch energy system.

We argue that the novel and radical interpretation of the deep core belief 'clean' has led to a new policy paradigm, which we name the renewable energy market policy paradigm. Below we investigate to what extent the policy core beliefs and secondary beliefs of the Dutch energy policy have changed.

\section{Policy core beliefs}

To strive for a clean, affordable and reliable electricity system, liberalization, privatization and clean and efficient energy formed the policy core beliefs of the Dutch energy policy to 2015. In the Netherlands, fundamental choices for liberalization and privatization respectively, are laid down in the Electricity Act of 1998 and the Independent Network Management Act of 2006. To safeguard the reliability, the responsibility for grid management was placed in public hands. In addition, market mechanisms were introduced on the supply side to secure the affordability of energy.

After the Paris Agreement the existing policy core beliefs have remained the same. The Dutch government expresses its belief that the transition towards a 'very' clean energy supply can be achieved with a liberalized and privatized market and by continuing stimulating renewable energy and energy efficiency (EZK 2016). However, prioritizing 'clean' makes it more difficult to secure the affordability and reliability of the energy system. In line with the European Commission (EC 2019), the Dutch Ministry of Economic Affairs and Climate (EZK 2018) expects that digitalization can enable the transition towards a clean, affordable and reliable energy system. So digitalization has been added as a new policy core belief within the Dutch renewable energy market policy paradigm. 
Driven by these policy changes, it is expected that central, fossil-based power plants are going to be replaced by large numbers of intermittent and often distributed, renewable energy sources. In certain parts of the Netherlands, the rapidly growing demand for transport capacity is already causing a queue of requests that prevents renewable energy sources such as wind and solar to be connected to the grid (EZK 2019). The demand for electricity is also increasing because of the electrification of other sectors such as heating and transport. As a result, the distribution network is becoming more complex to manage (Koirala et al. 2018; Lavrijssen 2017).

Besides putting more cables into the ground, the Dutch government advocates the use of digitalization to manage the grid in
TSOs but also DSOs need to become active managers of smart electricity grids. To facilitate this, adjustments need to be made at the secondary belief category of electricity grids to make it possible for DSOs to fulfill this role (RVO 2015).

Smart grid technologies facilitate the integration of large numbers of distributed generation by automatically balancing supply and demand and reducing electricity peaks. Smart grid technologies can refer to different subsystems within the energy system such as smart meter systems, smart home energy management systems, demand side-response, household storage, and the integration of electric-vehicles (Milchram et al. 2018). On the one hand, smart grids can help to deal with the increased complexity. On the other hand, since they increase the diversity

\section{Prioritizing 'clean' energy makes it more difficult to secure the affordability and reliability of the energy system.}

a smarter way (EZK 2018). More and more components within the energy system are already equipped with digital technologies that enable the collection and analysis of large amounts of data to improve the reliability and affordability of the energy system. In this way, digitalization could "help with better network management, assisting with the renewable generation intermittency problem, allowing more effective network monitoring and more efficient network operation" (Küfeoglu et al. 2019, p. 1).

\section{Secondary beliefs}

To implement the policy core beliefs of liberalization, privatization and clean and efficient energy, there are four main secondary belief categories covering the most important policy instruments. The categories relate to: 1) guidelines for electricity grid management, planning and operation, 2) the energy market design in which roles and responsibilities, non-discriminatory access for third parties and guidelines for a level-playing field are defined, 3 ) the promotion of clean energy to support energy efficiency measurements such as the roll out of the smart meter and subsidies for renewable energy and 4) the establishment of a consumer protection framework such as for price monitoring and monitoring of accessible information for consumers. We describe below how, as a result of the desired steep rise of renewable energy resources, the other three secondary beliefs might change and what role digitalization plays in it.

The new energy system should be "less polluting, more distributed and altogether smarter" (Edens 2017, p. 134). In the 'old' situation, demand for electricity was leading and power stations were adjusted accordingly. The Dutch electricity law held the transmission system operator (TSO) responsible to ensure that at all times the electricity fed into the network is the same as the electricity extracted from the network. In this situation the distribution system operator (DSO) was mainly responsible for 'burying copper in the ground'. In the new situation not only of actors and add new roles, smart grids also add extra complexity with regard to organizing the electricity market. As a result, new questions on data property and market access rights are raised (Milchram et al. 2018). Action is already being taken in the form of a legal regime for data access and data management that was proposed by the European Commission in the Electricity Directive and adopted by the European Parliament and Council in 2019 (EC 2019).

Access and control over data could also enable citizens and communities to play a more active role in the energy system. In combination with renewable energy sources such as solar panels, consumers can become prosumers that participate in the energy transition through online platforms (Kloppenburg and Boekelo 2019). Involvement of citizens and communities is even seen as one of the biggest challenges of the future energy system, a challenge where digitalization can help (Koirala et al. 2018). However, the changing role of citizens in the energy system also implies that changes are necessary at the secondary belief level of the consumer protection framework. Below we will highlight some challenges that relate to this.

\section{Policy issues related to convergence of electricity with digitization}

The former section showed that policy makers see digitalization as crucial for enabling the sustainable energy transition. The convergence of digitalization with electricity not only creates opportunities. Digital technologies such as robotics, big data, AI and digital platforms evoke a wide range of social issues (Kool et al. 2017, Royakkers et al. 2018). Important public values and human rights could be at stake such as privacy, equal treatment, autonomy and control over technology. It is increasingly acknowledged that the digitization of the Dutch energy 
system raises similar issues (Hollander et al. 2017; RLI 2018; Milchram et al. 2018; Kloppenburg and Boekelo 2019). If such concerns are not properly addressed they can form serious barriers for the development and adoption of digital technologies in the energy system.

This section analyses some policy issues pertaining to digitization of the electricity system by investigating the significance of digitization on various elements of the energy policy belief system. Based on academic literature research, we identify the following issues: digital security, data governance, equal distribution of costs and benefits and control as well as supervision of digitalization.

\section{A digital secure infrastructure}

The energy system is a critical infrastructure that is of great societal importance. In addition, certain functions and sectors, such as heating and transport, will become even more interconnected and interdependent. Given the crucial role of data for the energy market, digital security is a concern for all those sectors. Digitization not only makes the energy system more flexible, but also more vulnerable: for software errors, but also for unpredictable behavior by algorithms, and for cyberattacks (RLI 2018; Munnichs et al. 2017). The 'new' energy system is expected to consist of "both cyber and physical assets that are tightly integrated, and all of these assets must be protected" (Pérez-Arriaga and Knittel 2016, p. 67). Therefore, the 'new' deep core belief of safe should also be interpreted as digitally safe and the secondary beliefs related to the electricity grid must be equipped with a cybersecurity component.

\section{Data governance as a new core function}

The major policy change resulting from the convergence of digitalization and clean energy is putting data governance on the policy agenda. Data governance is becoming a core function for the renewable energy system (Pérez-Arriaga and Knittel 2016). In fact, data governance cannot be separated from digitalization as a policy core belief and should therefore also be integrated in all secondary belief categories. Below we highlight some of the policy challenges related to data governance.

The rationale for data governance is often unclear and remains vague by calling for "a fair competition for data" (Ducuing 2019 , p. 9). The notion of data governance should therefore be interpreted more concretely. In line with this vision, the Dutch Authority for Consumers and Markets (ACM) argues that the current data governance model is not sufficient to facilitate the energy transition since it is still based on the situation in which meter data was requested once a year and only market roles recognized by law had access to energy data. Therefore, the ACM advocates for energy data governance that is affordable, reliable, safe, protects the privacy of consumers and ensures that they have control over their data (ACM 2019). Additionally, we propose that the aforementioned social issues related to digitalization should also be integrated in the energy data governance model. This is currently not the case.
The Electricity Directive proposes a new market design that contains a legal framework for data governance with accompanying secondary beliefs such as that "Member States shall ensure that all eligible parties have non-discriminatory access to data under clear and equal terms, in accordance with the relevant data protection rules." (European Parliament and Council of the European Union, art. 23.2). These secondary beliefs related to the category 'electricity market design' give substance to the policy core of liberalization and privatization which are integrated into the energy data layer.

The Electricity Directive also states that energy data is to "include metering and consumption data as well as data required for customer switching, demand response and other services" (ibid). However, according to Ducuing (2019, p. 9): "it remains unclear what 'other services' concretely consist of". Data generation by most DERs, such as rooftop solar panels or electric cars, is taking place 'behind the meter' and are "hence not covered by traditional energy regulation" (Tagliapietra et al. 2019, p. 952). In addition, the use of these types of non-regulated data raises various issues in the field of autonomy, privacy, cybersecurity and equal treatment.

The Electricity Directive refers to the role of the data management operator (EC 2019). Given the expectation that due to the energy transition, the system task of DSOs will become increasingly important and that access to data is crucial for this, Pérez-Arriaga and Knittel (2016) argue in favor of combining the management of the physical network with the management of data. These scholars also state that non-innovative DSOs risk losing knowledge in the long term to efficiently manage the highly digitized electricity grid of the future (Enerquire 2018). In that case a takeover by "dominant tech companies, becoming operator of the digital work in the country distribution platform" could become an option (Tagliapietra et al. 2019, p. 951). Such an option directly raises the issue of how public governance of such large tech companies should be shaped in a democratic fashion. The dependence of democratic government on technical expertise and companies can also play a role at the local level. Milchram et al. (2018, p. 1253) state that "greater reliance on novel technologies in smart grids, which require more special knowledge, leads to perceptions that knowledge concentrated at private corporations is seen as source of power over municipalities".

\section{Promotion of sustainable energy: equal distribution of costs and benefits}

Clean energy and digitalization can undermine the justice of the current energy system in various ways. Roles, responsibilities, rights and obligations that were previously fair can in the (near) future contribute to an unfair distribution of costs and benefits. Purchasing solar panels or setting up a local energy community requires financial as well as social and technical skills. Even though prosumers and local energy communities can benefit from their investments in renewable energy, it is the general public who has to pay for the infrastructure that makes those investments possible. Moreover, trading of energy by communities 
is likely to put more strains on the grid in this way endangering its affordability and reliability (Kloppenburg and Boekelo 2019). On the other hand, prosumers and communities can also deliver the flexibility that is needed for matching energy supply and demand. Whether someone has the ability to be flexible depends on one's flexibility capital and other dimensions such as age or levels of digital inclusion. These flexibility conditions raise questions about 'flexibility justice' (Powells and Fell 2019). It is therefore important to find a fair balance between the money that active consumers earn and the system value of the services, such as flexibility, that they offer (Pérez-Arriaga and Knittel 2016).

\section{Consumer protection: control and supervision}

The promise of digitalization and smart grids in particular, is that they can contribute to more equitable and democratic energy systems. Smart grids enable the shift towards more small scale electricity generation and empower citizens to play a more active role. Milchram et al. (2018) wonder whether smart grids actually give 'power to the people'. Whether citizens will be able to benefit from the new opportunities will likely depend on their ability to invest and their (required) level of knowledge.

There is more to this, in recent decades the internet has become a Utopia for mass surveillance, mass behavioral experiments and, profiling and manipulating people on a large scale (Lanier 2018; Zuboff 2019). The internet is putting considerable pressure on people's privacy and autonomy. For example, Google's Nest smart thermostat can be "transformed into a spy that can not only report on the routines of the inhabitants of a certain home or office, but also on their cyber activities and provide a backdoor to their local network which could go unnoticed." (Hernandez et al. 2014, p. 7).

Whether smart energy systems strengthen or weaken people's autonomy and enhance the democratic controllability of the energy system, depends on the extent to which users have insight into and control over those algorithmic systems. According to the Dutch Authority for Consumers and Markets, the current situation is unclear and a new data governance model should clearly facilitate this right (ACM 2019). Therefore, it must be

\section{The core challenge is adequate energy data governance.}

clarified how and on what basis, automatic decisions are made and who is responsible for the decisions taken (Raad van State 2018). It is also important that supervisors remain able to control such processes (Jong et al. 2019). Also mushrooming energy platforms cause new opacities, dependencies and uncertainties for both consumers and prosumers (Kloppenburg and Boekelo 2019). From the point of view of autonomy, it is also crucial that energy consumers can make well-informed and optimal choices in a future intelligent energy system (Lavrijssen 2017).

\section{Conclusion}

The Paris Agreement in 2015 has led to a paradigm shift in the Dutch energy policy: from a fossil to a renewable energy market policy paradigm. The Paris climate treaty led to a reinforcement of the importance of the deep core belief 'clean' and the need for a shift towards a renewable energy system. Since policy makers see digitalization as crucial for enabling the sustainable energy transition, digitalization has become an important extra policy core belief of the renewable energy market policy paradigm. At the level of the secondary beliefs the categories seem to remain the same but the interpretation thereof will be strongly influenced by digitalization.

We showed that the far-reaching convergence of electricity and digitalization pursued by European and Dutch policy makers will raise new policy issues. The core challenge is adequate energy data governance. Digitalization also raises policy issues in the field of safety, consumer protection, democratic control and the equal distribution of costs and benefits in a digitized energy system. The speed with which the sustainable energy transition must take place and the foreseen crucial role of energy data to enable that transition, make these policy challenges urgent.

\section{References}

ACM - Autoriteit Consument en Markt (2019): Visiedocument datagovernance energie. Den Haag: Autoriteit Consument en Markt.

CBS - Centraal Bureau Statistiek (2019): Energieverbruik gedaald in 2018. Available online at https://www.cbs.nl/nl-nl/nieuws/2019/16/ energieverbruik-gedaald-in-2018, last accessed on 12.04.2020.

Ducuing, Charlotte (2019): Data as infrastructure? A study of data sharing legal regimes. In: Competition and Regulation in Network Industries, online first, p. 19

EC - European Commission (2019): Clean Energy for All Europeans. Brussels: European Commission.

Edens, Marga (2017): Public value tensions for Dutch DSOs in times of energy transition. A legal approach. In: Competition and Regulation in Network Industries, 18 (1-2), pp. 132-149.

European Parliament; Council of the European Union (2019): Directive (EU) 2019/944 on common rules for the internal market for electricity and amending Directive 2012/27/EU. In: Official Journal of the European Union L 158, pp. 125-199.

EZ - Economische Zaken (2008): Energierapport 2008. Den Haag: Ministerie van Economische Zaken.

EZK - Economische Zaken en Klimaat (2016): Energieagenda. Naar een $\mathrm{CO}_{2}-$ arme energievoorziening. Den Haag: Ministerie van Economische Zaken en Klimaat.

EZK (2018): Nederlandse Digitaliseringsstrategie. Nederland digitaal. Hier kan het. Hier gebeurt het. Den Haag: Ministerie van Economische Zaken en Klimaat.

EZK (2019): Gevolgen van het gebrek aan netcapaciteit voor duurzame elektriciteitsprojecten. Den Haag: Ministerie van Economische Zaken.

EZLI - Economische Zaken, Landbouw en Innovatie (2011): Energierapport 2011. Den Haag: Ministerie van Economische Zaken, Landbouw \& Innovatie. 
Hall, Peter (1993): Policy paradigm, social learning, and the state. The case of economic policy making in Britain. In: Comparative Politics 25 (3), pp. 275-296.

Hernandez, Grant; Arias, Orlando; Buentello, Daniel; Jin, Yier (2014): Smart nest thermostat. A smart spy in your home. Available online at https:// www.blackhat.com/docs/us-14/materials/us-14-Jin-Smart-Nest-ThermostatA-Smart-Spy-In-Your-Home-WP.pdf, last accessed on 07.05.2020.

Hollander, Guus de; Vonk, Marijke; Snellen, Daniëlle; Hiddo Huitzing (2017): Mobiliteit en elektriciteit in het digitale tijdperk. Publieke waarden onder spanning. Den Haag: Planbureau voor de Leefomgeving.

Jong, Roos de; Kool, Linda; Est, Rinie van (2019): This is how we put Al into practice based on European Values. Den Haag: Rathenau Instituut.

Kern, Florian; Howlett, Michael (2009): Implementing transition management as policy reforms. A case study of the Dutch energy sector. In: Policy Sciences 42 (4), pp. 391-408.

Kloppenburg, Sanneke; Boekelo, Marten (2019): Digital platforms and the future of energy provisioning. Promises and perils for the next phase of the energy transition. In: Energy Research \& Social Science 49, pp. 68-73.

Koirala, Binod; Oost, Ellen van; Windt, Henny van de (2018): Community energy storage. A responsible innovation towards a sustainable energy system? In: Applied energy 231, pp. 570-585.

Kool, Linda; Timmer, Jelte; Royakkers, Lambèr; Est, Rinie van (2017): Urgent upgrade. Protect public values in our digitized society. Den Haag: Rathenau Instituut.

Küfeoglu, Sinan; Gaomin, Liu; Anaya, Karim; Pollitt, Michael (2019). Digitalisation and new business models in energy sector. Energy Policy Research Group, University of Cambridge, working paper 1920. Available online at https://www.eprg.group.cam.ac.uk/wp-content/uploads/2019/06/1920-Text. pdf, last accessed on 07.05.2020.

Lanier, Jaron (2018): Tien argumenten om je sociale media-accounts nu meteen te verwijderen. Amsterdam: Uitgeverij Business Contact.

Lavrijssen, Saskia (2017): Power to the energy consumers. In: European Energy and Environmental Law Review 26 (6), pp. 172-187.

Markard, Jochen; Suter, Marco; Ingold, Karin (2016): Socio-technical transitions and policy change. Advocacy coalitions in Swiss energy policy. In: Environmental Innovation and Societal Transitions 18, pp. 215-237.

Milchram, Christine; Hillerbrand, Rafaela; Kaa, Geerten van de; Doorn, Neelke; Künneke, Rolf (2018): Energy justice and smart grid systems. Evidence from the Netherlands and the United Kingdom. In: Applied Energy 229, pp. 1244-1259.

Munnichs, Geert, Kouw, Matthijs; Kool, Linda (2017): Een nooit gelopen race. Over cyberdreigingen en versterking van weerbaarheid. Den Haag: Rathenau Instituut.

Pérez-Arriaga, Ignacio; Knittel, Christopher (2016): Utility of the future. An MIT Energy Initiative response to an industry in transition. Cambridge, MA: MIT.

Powells, Gareth; Fell, Michael (2019): Flexibility capital and flexibility justice in smart energy systems. In: Energy Research \& Social Science 54, pp. 56-59.

Raad van State (2018): Ongevraagd advies over de effecten van digitalisering voor de rechtsstatelijke verhoudingen. Den Haag: Raad van State.

Royakkers, Lambèr; Timmer, Jelte; Kool, Linda; van Est, Rinie (2018): Societal and ethical issues of digitization. In: Ethics and Information Technology 20 (2), pp. 127-142. DOI: 10.1007/s10676-018-9452-x.
RVO - Rijksdienst voor Ondernemend Nederland (2015): Innovatieprogramma Intelligente Netten. Position paper kennis- en leertraject - Thema weten regelgeving. Utrecht: Rijksdienst voor Ondernemend Nederland.

RLI - Raad van Leefomgeving en Infrastructuur (2018): Stroomvoorziening onder digitale spanning. Den Haag: Raad voor de leefomgeving en infrastructuur.

Sabatier, Paul; Jenkins-Smith, Hank (1993): Policy change and learning. An advocacy coalition approach. Boulder: Westview.

Sabatier, Paul; Weible, Christopher (2007): The advocacy coalition framework. An assessment. In: Paul Sabatier (ed.): Theories of the policy process. Boulder: Westview, pp.189-220.

Salas Girones, Edgar; Est, Rinie van; Verbong, Geert (2019): Transforming mobility. The Dutch smart mobility policy as an example of a transformative STI policy. In: Science and Public Policy 46 (6), pp. 820-833.

Tagliapietra, Simone; Zachmann, Georg; Edenhofer, Ottmar; Glachant, JeanMichel; Linares, Pedro; Loeschel, Andreas (2019): The European Union energy transition. Key priorities for the next five years. In: Energy Policy 132, pp. 950-954.

TK - Tweede Kamer (1995): Derde energy memorandum. Den Haag: Ministerie van Economische Zaken.

Zuboff, Shoshana (2019): The age of surveillance capitalism. The fight for a human future at the new frontier of power. London: Profile Books.

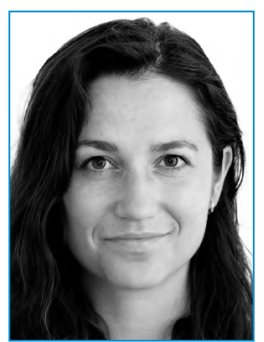

\section{ROMY DEKKER}

has been working as a researcher at the Rathenau Institute since 2018. She is currently working on a project about the convergence of digitalization and clean energy. Romy completed a Bachelor and Masters in Cultural Anthropology and Development Sociology.

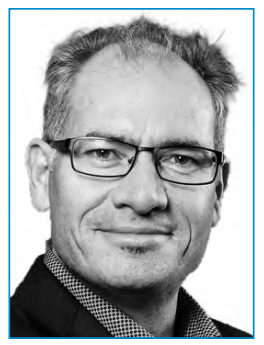

PROF.DR.IR. RINIE VAN EST

coordinates research within the theme Digital Society. He is involved in the field of energy transition and digital transition. He joined the Rathenau Instituut in 1997. Since 2000, he also works parttime at the Eindhoven University of Technology, where he currently holds the chair of Technology Assessment and Governance. 